$1-8-2020$

\title{
Fluid Identity Play: A Case Study of a Bilingual Child's Ethnic Identity Construction Across Multiple Contexts
}

Hyonsuk Cho

University of North Dakota, hyonsuk.cho@UND.edu

X. Christine Wang

How does access to this work benefit you? Let us know!

Follow this and additional works at: https://commons.und.edu/tlpp-fac

Part of the Bilingual, Multilingual, and Multicultural Education Commons

\section{Recommended Citation}

Hyonsuk Cho and X. Christine Wang. "Fluid Identity Play: A Case Study of a Bilingual Child's Ethnic Identity Construction Across Multiple Contexts" (2020). Teaching, Leadership \& Professional Practice Faculty Publications. 8.

https://commons.und.edu/tlpp-fac/8

This Article is brought to you for free and open access by the Department of Teaching, Leadership \& Professional Practice at UND Scholarly Commons. It has been accepted for inclusion in Teaching, Leadership \& Professional Practice Faculty Publications by an authorized administrator of UND Scholarly Commons. For more information, please contact und.commons@library.und.edu. 
Running head: Fluid Identity Play

Fluid Identity Play: A Case Study of a Bilingual Child's Ethnic Identity Construction Across Multiple Contexts

*Hyonsuk Cho, University of North Dakota

X. Christine Wang, State University of New York at Buffalo

*Corresponding author.

Hyonsuk Cho, College of Education and Human Development, University of North Dakota. 231

Centennial Dr Stop 7189, Grand Forks, ND 58201, USA

Email: hyonsuk.cho@und.edu 


\begin{abstract}
Informed by positioning theory as well as a nexus of multimembership, the year-long case study examined how a 7-year-old Korean American bilingual child, Meeso, constructed her ethnic identity across different educational contexts. Data were collected through observations of Meeso's interactions with her monolingual and bilingual peers and teachers. Discourse analysis revealed that Meeso constructed fluid ethnic identity positionings depending upon how she desired to position herself and to be positioned by others. We also identified that the social context, language proficiency, and peer dynamics were related to the process. Based on the findings, we discuss the roles of context, language, and peer interaction for bilingual students' ethnic identity development.
\end{abstract}

Keywords: bilingual children, discourses, ethnic identity, multiple contexts, positioning 


\section{Fluid Identity Play: A Case Study of a Bilingual Child's Ethnic Identity Construction Across Multiple Contexts}

Ethnic identity refers to “one's sense of self as a member of an ethnic group” (Phinney, 1990, p. 63). Ethnic group membership plays a critical role in identity development (Tajfel \& Turner, 1986). It is important to understand how bilingual children develop their ethnic identity because it can shed light on the ways they use the different languages they speak and draw upon diverse cultural resources to create meaningful interactions with family, teachers, and peers and to build a sense of belonging within various communities.

However, there is a gap in the existing literature on children's ethnic identity formation and negotiation. On the one hand, research that uses qualitative or discursive research methods to investigate ethnic identity mostly focus on teenagers (e.g., Harklau, 2000; Gonzalez, 2009; Yoon, 2015). Due to differences in cognitive and social abilities, the ethnic identity development of teenagers and young children can be different. Developmentally, adolescents possess socialcognitive maturity in understanding how their ethnic identity impacts their experiences, whereas young children are only beginning to identify and categorize themselves and others using ethnic or racial labels (Quintana, 1998). On the other hand, previous research with young children mainly investigate ethnic and racial identification, preferences, biases, and attitudes (Connolly, 2011; Doucet et al., 2018). These studies, which tend to take a cognitive or developmental approach, and use experimental or quantitative methods do not examine the discursive aspect of identity construction. As a result, we have limited understanding of how different interactions shape young bilingual children's dynamic ethnic identity, in particular how their ethnic identity emerges and changes in interactions across multiple social contexts. To address this need, we 
investigated the following research question: How does a young bilingual child construct her ethnic identity across different educational contexts?

\section{Theoretical Framework and Literature Review}

This study is grounded in positioning theory and the conception of identity as a nexus of multimembership and is informed by literature on ethnic identity as the interplay of self, context, language, and interaction.

\section{Identity as Positioning}

Positioning theory views identity as the ongoing positioning of individuals in interactions with others (Davies \& Harré, 1999; van Langenhove \& Harré, 1999). Positioning refers to “the discursive process whereby people are located in conversations as observably and subjectively coherent participants in jointly produced storylines" (Davies \& Harré, 1999, p. 37). Thus, positioning theory focuses on the analysis of interpersonal encounters from the discursive perspective (Hollway, 1984). Within a conversation, each interlocuter positions the other (i.e., “interactive positioning”) while simultaneously positioning himself or herself (i.e., "selfpositioning"; Davies \& Harré, 1990, p. 48). How one views one's own ethnicity is not necessarily consistent with others' views of the one's ethnicity, and one's self-ascription can reflect 'other-imposition'-i.e., other people's descriptions of them (Brown, 2009). Selfascription is one's own definition of one's ethnic identity voluntarily defined by oneself, whereas other-imposition concerns externally defined ethnic labels involuntarily defined by others (Jenkins, 1994).

From the perspective of positioning theory, ethnic identity is more than "terms" themselves (e.g., Korean American, Asian American) as it is determined by the "discourses in which [different concepts of identity positionings] are embedded" and can depend upon the 
identities of one's interlocutors (Kang \& Lo, 2004, p. 95). That is, ethnic identity is not a fixed term but a positioning that is constructed in particular local interactions (Hall, 1990). Thus, ethnic identities are "slippery," negotiated constructs that dwell between the categories of selfascription and other-imposition (Kang \& Lo, 2004, p. 112).

\section{Identity as a Nexus of Multimembership}

When an individual belongs to multiple communities of practice, complex relationships with other individuals and the varied environments of the diverse communities can lead to “multiple selves/identities” (Hornberger \& Wang, 2008, p. 7). Because people shape different parts of themselves through various forms of participation in different communities of practice, an identity is better viewed as "a nexus of multimembership" than a single trajectory (Wenger, 1998, p. 159). According to Wenger (1998), the notion of a nexus does not indicate the merging of different identities; rather, "in a nexus, multiple trajectories become part of each other, whether they clash or reinforce each other" (p. 159). In other words, identity is, at the same time, a unity and a set of disconnected parts of the self because different forms of identification complement, enhance, and conflict with one another (Wenger, 1998). The concept of multimembership can be usefully employed to help us understand ethnic identity construction across different communities of practice.

\section{Ethnic Identity as the Interplay of Self, Context, Language and Interaction}

Studies of bilingual individuals' ethnic identity have demonstrated the interconnectedness of ethnic identity, self, context, language, and interaction. Harklau (2000), for example, showed how the same immigrant students could take on different identities depending on the institutional context—valuing their immigrant experience versus devaluing their resources or considering them to be deficient. This is further illustrated by other studies. On the one hand, Toohey (1998) 
showed that certain classroom practices (e.g., English learners were seated at the front of the room and children speaking the same first languages were not seated together) could impede opportunities for the development of multicultural ethnic identities by generating the representation of bilingual students as deficient in English and discouraging the empowerment of their competence and expertise. On the other hand, a supportive educational context can promote empowering ethnic identity construction. For example, the heritage language school offered a student a way to capture his ethnic identity "pure Gujarati person" that was not available to him in other English language-dominant settings (Creese, Bhatt, Bhojani, \& Martin, 2006, p. 34).

Other research has focused on the interrelatedness of language and ethnic identity. Individuals with more proficient heritage language skills were found to have stronger ethnic identities (Cho, 2000; Kang, 2013). However, language proficiency is not necessarily proportional to ethnic identity because ethnic identity is a multifaceted representation that goes beyond language proficiency (Brown, 2009). An individual who demonstrates a strong ethnic identity associated with her heritage language can have a low level of heritage language competence, and vice versa (Jo, 2001; Pavlenko \& Blackledge, 2004).

Another line of research has focused on flexibility of language choice in relation to ethnic identity. Bilingual speakers can choose one language over another, and such choices can represent part of their ethnic identities (Rampton, 1995). For example, Kang (2013) showed that Korean American students perceived their ethnic identities to lie at different points along a continuum between the two worlds of American-ness and Korean-ness depending upon their daily situations. English was mainly used as a communication tool, while Korean was used to talk about childhood memories, food, culture, and kinship. 
In studies of the influence of peer interactions on children's or young adults' ethnic identity, social interaction with same-ethnic peers was observed to increase ethnic identity because such interactions offer children opportunities to experience and express their ethnicity (Phinney, Romero, Nava, \& Huang, 2001). In Thompson (2006), one student's connection with a group of Korean Americans increased her interest in her Korean identity and affected her positive sense of self-identity as both an American and a Korean. Gonzalez (2009) reported that the support of other Mexican American peers who understood the ethnic self of a Mexican American youth reinforced her ethnicity as a Mexican. Even among same-ethnic peers, differences in language proficiency, personal experiences, and cultural knowledge can affect each child's ethnic identity positioning differently. For example, Gujarati-English bilingual children in Creese et al. (2006) separated themselves from peers who had just arrived in Britain speaking only Gujarati by calling them "freshies." The students considered a lack of bilingualism to be an indicator of a singular ethnicity. Second-generation children's positive sense of their ethnic identity has been shown to be associated not only with increased preferences for socializing with children of their own ethnicities but also with increased preferences for socializing with children from ethnic outgroups (Marks, Szalacha, Lamarre, Boyd, \& Coll, 2007). Ethnic identity has also been observed to moderate children's view toward multiethnicity. In Yoon (2015), peers with a multicultural view promoted an immigrant student's inclusion, while peers with a monocultural view made an immigrant student feel excluded in and out of the classroom.

Research on ethnic identity of mostly adolescents has revealed ways in which ethnic identity construction is related to particular social contexts, language proficiency, language choice, and peer group interactions (Bucholtz \& Hall, 2005; Harklau, 2000; Kang \& Lo, 2004; 
Rampton, 1995). Less attention has been paid to the ways in which young bilingual children who are beginning to be aware of their bilingual/bicultural abilities construct their ethnic identities and how membership within different communities affords bilingual children's ethnic identity construction. Our research on young child's ethnic identity positioning and discourse is an attempt to address this gap and will extend the existing body of literature on children's ethnic identity formation and negotiation (Connolly, 2011; Doucet et al., 2018).

\section{Methods}

Through a study of the particularity and complexity of a single case (Yin, 2018), we intend to present a "telling case" that shows "how general principles deriving from some theoretical orientation manifest themselves in some given set of particular circumstances" (Mitchell, 1984, p. 239). We observed the focal child's social interactions in different types of educational settings and focused on the analysis of discourse in these settings in order to illustrate the child's ethnic identity positionings. Our discourse analytic approach is linked to our theoretical perspective. Because ethnic identity is fluid rather than fixed or pre-determined, the analysis of discourse is necessary to shed light on how the ethnic identity of a bilingual child is represented and negotiated in various social interactions that are available to the child at different times and places (Brown \& Yule, 1983).

\section{Participants}

When the study began, the focal child, Meeso (all names are pseudonyms), was a sevenyear-old first grader who was born and raised in the United States. She was a cheerful and thoughtful girl. Meeso's academic performance in first grade was above average in general. Her reading achievement level was "reading above grade level." 
Meeso's parents were Koreans who had immigrated to the U.S. three years prior to her birth. Meeso's father studied religion and eventually took a job as a clergy member in the U.S. Meeso's mother was a stay-at-home mother in her late 30s who volunteered in the KoreanAmerican community. Meeso had a younger sister (3 years old). Meeso's parents mainly used Korean at home, and Meeso communicated with them and her younger sister in Korean, although Meeso occasionally used English words in a Korean sentence. Her parents hoped that Meeso would not forget that she was Korean, so they picked Meeso as her first name and Gloria (an American name) as her middle name. Meeso's family lived in a city in Western New York, where the Korean population was approximately $3 \%$ of the total population (U.S. Census Bureau, 2010). Meeso had a limited number of opportunities to use Korean when she was not at home or in her family's Korean-American church and its affiliated Korean heritage language school.

While Meeso is the focal child of this case study, secondary participants in the study include her elementary school teachers, her classmates in the public elementary schools, her Korean language teacher, and her bilingual peers in the Korean school. More information of the secondary participants is provided in the next section.

\section{Research Sites}

Public elementary schools. The Intercultural Elementary School (IES) where Meeso attended first grade was the only school in its district that offered English as a Second Language (ESL) services. Most students at the school were Caucasian (over 50\%), while Asian, Black, and Hispanic students made up 18\%, 17\%, and 9\% of the student body (NCES, 2015). In Meeso's first grade classroom, there were two other Korean-English-speaking students-Hana (female) and Myoungsoo (male) — both were born in South Korea and moved to the United States when 
they were quite young. The classroom teacher was Mrs. Madison (female Caucasian) who had taught kindergartners and first graders for 15 years.

Due to Meeso's fluency in English, Meeso was not required to take the ESL program at IES, and for $2^{\text {nd }}$ grade she moved to another school in the same district-May Elementary School (MES), which was close to her house. The student population of MES was less diverse than at IES or most other schools in the state. It was approximately $74 \%$ White, with Black, Asian, and Hispanic students making up $16 \%, 5 \%$, and $4 \%$ of the student body (NCES, 2015). In Meeso's second grade class at MES, all students were proficient in English, and only one other student was from an immigrant family. Unlike her experience at IES, Meeso had no one with whom to speak Korean at MES. In general, there were more students with diverse linguistic and cultural backgrounds at IES. Her second-grade classroom teacher was Mrs. Larsson (female Caucasian) who had taught second or third graders for 11 years.

Korean heritage language school. The Sunday Korean school was small, and there were only four to six students in the 3-5-year-old age group and five to six in the 6-8-year-old age group. The 6-8-year-old age group was further divided into two proficiency groups-beginning and developing. Meeso belonged to the developing group. Meeso's teacher, Mr. Park, who was also the school principal and father of one of Meeso's classmates, taught all areas of Korean language — speaking, listening, reading, and writing. Mr. Park volunteered to teach Korean, even though he had a full-time job as a scientist outside the school. During the interview with Mr. Park, he said that while it was important for his students to learn Korean language and culture, he understood that his students' Korean learning could be slow because they were acquiring two languages. He usually did not correct his students' incorrect or inappropriate language use (e.g., non-honorific language) or restrict the use of English in his Korean classroom. 


\section{Data Collection and Analysis}

The major data source for this study was approximately 77 hours of observations (51 hours in two elementary schools and 26 hours in the heritage language school), which were audio or video recorded. During the year-long fieldwork, the first author, a native Korean speaker, visited IES 24 times (during the fall of Meeso's $1^{\text {st }}$ grade), MES 6 times (during the spring of $2^{\text {nd }}$ grade), and the Korean school 18 times. Each visit lasted one to three hours. With young children, it is challenging to discuss abstract and metacognitive thinking about self-identity. Thus, instead of conducting formal interviews with the focal child, impromptu informal questions were asked when appropriate (e.g., “Do you sometimes talk with Hana in Korean?”). Still, the major source of data was observation of the focal child's interactions with her peers and teachers (transcribed audio/video data), which we believed would best capture the young child's identity positioning.

The unit of analysis was the "speech events" or "communicative events" (Hymes, 1974; Saville-Troike, 2003). A speech event was defined as a conversation on one topic among the same participants in the same setting. A speech event ended with a change in participants, topic, or setting. The transcript below is an example of an ethnic identity-related event. This conversation between Meeso and her classmate Youngseo started after the Korean language teacher distributed the worksheets and ended when the teacher started his instruction.

\section{Excerpt 1}

1Meeso: Can you call me Gloria? (turning to Youngseo who was sitting right next her after writing "Gloria" on the worksheet)

2Youngseo: Why? (looking at Meeso showing surprise)

3Meeso: Because that's my middle name. 
4Youngseo: I know, but Meeso is your first name.

5Meeso: But I want to be Gloria.

Ethnic identity-related events included not only the use of specific race or nationality terms such as "American" or "Korean" but also discursive positionings represented in the words and sentences. A total of 32 speech events (13 in the English-speaking schools, 19 in the Korean school) were identified as ethnic identity-related events. We then grouped these events to identify the personal and situational circumstances that most affected Meeso's ethnic identity. After we looked for patterns, we analyzed the discourses in selected excerpts. As neither positioning theory nor the understanding of identity as a nexus of multimembership are methods or analytic techniques (Ritchie, 2002; Wenger, 1998), we used them instead as conceptual lenses to interpret the discourses. The selected excerpts illustrate how identity is positioned within interaction. In addition, the excerpts from different educational settings represent how multimembership can lead to dynamic ethnic identity positioning.

\section{Findings}

This finding section presents examples that illustrate Meeso's fluid ethnic identity play and explain how she positioned herself or was positioned by others in different interactional settings.

At the Korean heritage language school, Meeso tended to assert her American-ness. This is vividly illustrated in Excerpt 2 below, where she proclaimed, "I was born in the United States, and I go to an American school" (Line 1). Similarly, in Excerpt 1 (above) she declared, "I want to be Gloria" (Line 5) and not "Meeso." These are her clearest statements that she associated herself with an American identity at the Korean language school.

Excerpt 2 
(Korean is italicized and translated in brackets.)

1Meeso: nanun mikukeyse tayenassko mikuk hakkyo ka. [I was born in the United States, and I go to an American school.]

2Teacher: kulem Meeso mikuk salamiya? hankuk salamici, kuchi? [Then are you American? You are Korean, aren't you?]

3Meeso: e. [Yes.]

4Teacher: kulem hankukmal ssulcul alayaci. [Then you should know how to write in Korean.]

5Meeso: I know, but I don't know a lot of Korean.

6Teacher: That's ok because you are learning it.

7Meeso: But I'm still the worst one.

8Teacher: No, you are not.

9Meeso: Yes, I am.

Meeso's claim of her American identity in the Korean school was mainly associated with her struggles of learning Korean and her bilingual/bicultural ability, which led her to bring up her American-ness to justify her lack of competence in Korean. This is most evident in Excerpt 2, when the teacher imposed an ethnic identity on Meeso by emphasizing that she needed to learn Korean because she was Korean (Lines 2, 4). Meeso agreed with the teacher but expressed a lack of self-confidence (Lines 5 and 7). She also complained to the first author several times, “hankul hakkyo [Korean school] teaches hard stuff" and "nemu elyewe [too difficult]." Her struggles with Korean were partly due to unique features of Korean (e.g., word spacing and the different ways that the final consonants at the end of Korean syllables are pronounced). Thus, claiming her American identity in this context helped alleviate Meeso's frustration with learning Korean. In 
Excerpt 2, however, Meeso still accepted the teacher's positioning of her as Korean (Line 3). It is notable the teacher's emphasis on her Korean identity was meant to be a motivator for learning and mastering the Korean language, even though this was the very source of Meeso's frustration. This sheds light on Meeso's decision to accentuate her American identity in this context, even though her teacher was explicitly positioning her as a Korean (Line 2).

Conversely, in the English-speaking elementary schools, Meeso was proud of being able to speak Korean. Meeso confidently said "I speak Korean. Hana does. Myoungsoo does” when Tyson asked her if Meeso could “talk Korean too.” In response to Meeso's answer (“yes”), Tyson said "Yeah, I wish I could talk Korean" (See Excerpts 4 and 5 for more examples). Nevertheless, Meeso did not want to be positioned as being different from her American peers (see Excerpt 4). In her first-grade elementary school (IES), Meeso often insisted, "Gloria, that's my middle name." Such a statement reflected her desire to connect with her English-speaking classmates, as people often use names that "allow them to exist in social networks of which they desire to be a part" (Thompson, 2006, p. 203).

Meeso's classmates at IES who were interested in Meeso's ethnic background and the Korean language provided opportunities for her to share personal narratives related to Korea. She would share with her classmates the stories of her grandmother living in Korea, her experiences visiting Korea, and Korean books she had at home. Also, Meeso taught Korean words and corrected her English-speaking peers' pronunciation.

During an art class at IES in which the teacher talked about Vincent van Gogh's work, Meeso shared the fact that she read a book about van Gogh in Korean. Similarly, at MES, when a peer named Elizabeth said that she had watched the movie based on the book the class was going 
to read, Meeso mentioned that she had watched the same movie in Korean at her Korean language school (Excerpt 3, Lines 2-4).

Excerpt 3

1Teacher: This book is called You are Special.

2Elizabeth: I saw the movie on the TV.

3Teacher: Very good. You watched it right on the television.

4Meeso: I saw it on the computer, but the language was Korean because I was in um... hankul hakkyo [Korean language school]. (Two seconds later) Korean school.

5Teacher: Wow! Very nice. So you watched it in Korean. I wonder if they have it in other languages besides Korean, too.

Line 4 is interesting in that Meeso hesitated (uttering "um") before saying "hankul hakkyo." Meeso unconsciously or consciously positioned that she was part of the rest of group who spoke English but could also speak another language. While Meeso was conscious of her own language practice, the teacher's positioning shaped Meeso's identity positioning as well. After the teacher learned that Meeso saw the movie in Korean and spoke Korean, she says “Wow! Very nice!” (Line 3). This exclamation is significant as it may reify Meeso's Korean identity in a way that exoticizes it.

However, the most telling ethnic-identity-relevant exchange appeared at the beginning of the conversation in the following excerpt.

\section{Excerpt 4}

1Tyson: Where did you use to live? Where were you born?

2Meeso: I was born in the United States. I visited Korea when I was one year and half and learned some Korean and came back. 
3Tyson: Tell me some Korean. Tell me some Korean then.

4Meeso: Ap-pa means dad. Em-ma means mom. And $O$-ri means duck. Ae-gi means baby. En-ni means sister. Op-pa means brother.

5Tyson: Op-pa again?

6Meeso: Op-pa (slowly) means brother, not dad. And...

7Tyson: What else? What's sister?

8Meeso: Sister? En-ni (slowly). I already said that before brother. Um, Hak-kyo means school.

9Tyson: What else?

10Meeso: I don't know everything in Korean. I sometimes talk in English at home. I don't know how to say all of Korean.

When Tyson assumed that Meeso was born somewhere else, she made clear that she was born in the U.S. and that she "visited" Korea but "came back" (Line 2). Her words were a subtle confirmation of her own American-ness. She was happy to share her knowledge of Korean and stories about Korea when asked or challenged (Line 3). However, when she was positioned as “other” by her classmate (Lines 1, 9), she gently pushed back to assert her American identity. The differentiation between brother and dad (Lines 5,6) is important to note in understanding Meeso's ethnic identity positioning. From lines 4-8 in the excerpt, Meeso positioned herself as someone who has expertise in the Korean language because her Korean knowledge was challenged (Line 3). Pointing out the slight pronunciation difference between $A p-p a(\mathrm{dad})$ and $O p$ - $p a$ (brother) and knowing a possibility of confusion for Tyson demonstrates her knowledge of Korean. However, Meeso fortified her American identity by revealing information about her American identity and practices (Line 10), which demonstrates her fluid ethnic identity play. 
A different pattern of Meeso's fluid ethnic identity positioning and play was observed in interactions with a group of Korean-English bilingual peers in her first-grade classroom. As can be seen in the following excerpt (Excerpt 5), she wanted to be part of IES's Korean group and did not want her Korean identity to be questioned.

\section{Excerpt 5}

1Hana: We all speak Korean.

2Meeso: Korean table!

3Myoungsoo: (Talking to Meeso) You can speak Korean, but you are not from Korea. You're from the United States.

4Meeso: I visited Korea after I was born.

When three Korean-English bilingual children (Meeso, Hana, and Myoungsoo) were assigned to the same table during a writing session, Hana observed, "We all speak Korean" (Line 1) and Meeso excitedly named the group the "Korean table" (Line 2). Myoungsoo, however, questioned Meeso's Korean identity and refused to position Meeso's ethnic identity as the same as his (Line 3) because Meeso was born in the U.S. while the other two were born in Korea (Line 3). In response, Meeso tried to position herself as Korean by emphasizing "I visited Korea after I was born." This directly contradicted her exchange with Tyson in Excerpt 4 (Line 2). We see Meeso took on her American and Korean identities with ease when her classmates positioned her as other.

\section{Discussion}

This section explains the ways in which Meeso's fluid ethnic identity play and positioning are related to different social contexts, her language practices and proficiency, her peer interaction, and her multi-memberships in different communities. 


\section{Interactional Contexts}

It is important to note that Meeso's fluid ethnic identity positioning and play were mostly observed in linguistically and culturally diverse contexts (e.g., IES). The opportunities for such identity play and positioning were rare after she moved to MES in $2^{\text {nd }}$ grade. MES was a less culturally and linguistically diverse school, and it afforded her fewer opportunities to play and experiment with her identities. This finding is consistent with other studies with teenagers that found when bilingual students' language and culture are valued and promoted at school, they are more willing and able to share their linguistic and cultural knowledge and experiences (Gonzalez, 2009; Harklau, 2000; Toohey, 1998; Yoon, 2015). In contrast, treating students with immigrant backgrounds as novices in English can negatively affect both their identities and their attitudes toward classroom learning (Harklau, 2000). Focusing on the lack of English skills instead of acknowledging the bilingual/bicultural abilities of students can even hinder the development of their bilingual identity (Toohey, 1998). To further understand what would be a good balance of the relevant contexts for children's fluid identity play and positioning — valuing and supporting heritage language and cultures without pigeonholing or positioning children as other - a longitudinal comparison of children in different contexts is needed in the future.

\section{Language Practices and Proficiency}

Our study has demonstrated that Meeso’s bilingual practices played an important role in helping her decide who she wants to be and how she wants to be seen by others across different situations and contexts. Although we recognize that the constructs of bilingualism and ethnic identity are distinct, our data suggests considerable overlap between the two. In linguistically and culturally diverse contexts, Meeso used all the language resources she possessed flexibly to position her ethnic identity in interaction. For bilingual speakers, being able to use both their 
heritage language and English has been shown to indicate flexibility with their bilingualism and ethnic identities (Tse, 2000; You, 2005). Depending on how Meeso decided to position herself and how she wanted to be positioned in various situations, she utilized her bilingual ability to assist the positioning of her ethnic identity.

Meeso strategically accentuated her American-ness or Korean-ness depending upon her perceived Korean language proficiency in the moment (see Excerpts 2 and 4). Previous studies reported different relationships between ethnic identity and language proficiency. In some cases, more proficient heritage language learners tended to have stronger ethnic identity (e.g., Cho, 2000), while in other cases the opposite was true (Jo, 2001; Pavlenko \& Blackledge, 2004). As a case study of a young child, our study extends previous research that has mainly focused on the ethnic identity of young adults. Aligning with findings from studies on adolescents and adults (Cho, 2000; Jo, 2001), our study shows that language proficiency played an important role in a seven-year-old child's ethnic identity formation. However, our study demonstrates that a child's perceived relative level of language proficiency within a certain group can affect stronger or weaker ethnic identity positioning in the moment. That is, especially for a young child, their perceived and relatively low language proficiency can contribute to the conflict and negotiation of their ethnic identity in the particular situation. In the same vein, perceived and relatively high language proficiency can lead to ethnic pride in the moment.

\section{Peer Interaction}

In different peer groups' reactions and positionings, Meeso fluidly experimented with her ethnic identities. This is illustrated by the contrasting framing of her visit to Korea with her American peers (Excerpt 4) and her Korean peers (Excerpt 5). In both cases, she was pushing back against being positioned as other. Such positioning was done implicitly by the American 
peer (Excerpt 4) and explicitly by the Korean peer (Excerpt 5). Interactions like these allowed her to exercise and develop her fluid identity and to utilize "access strategies" for being included in her peer cultures (Corsaro, 1997).

Studies with adolescents have shown that positioning in peer interaction affects an individual's perceived ethnic identity (Creese et al., 2006; Kang \& Lo, 2004; Phinney et al., 2001; Yoon, 2015). Our findings exhibit a similar pattern, where a seven-year-old child's ethnic identity formation process was considerably influenced by her peers (e.g., explicit or implicit other-imposition). Similar to the multilingual adolescents in other studies (Creese et al., 2006; Rampton, 1995), Meeso, using her multilingual resources, flexibly and strategically changed her ethnic identity depending upon which peer group she wanted to be in (e.g., an English-speaking peer group, a Korean-speaking peer group).

While our study demonstrates the similarities and differences between young children and adolescents in terms of ethnic identity construction through peer interactions, there is a need for research that examines how a multilingual individual's ethnic identity develops beginning early childhood. As children get older, other features of the school context (e.g., more exposure to diversity, more self-segregation by ethnicity; Huang \& Stormshak, 2011) and many changes that occur during adolescence (e.g., pubertal changes, or transitional periods; Umaña-Taylor et al., 2014) can affect the peer relationships and play a significant role in ethnic identity construction process in early to middle adolescence. Such developmental and contextual differences can make the ethnic identity formation process different between young children and older children.

\section{Nexus of Multimembership Across Communities}


Our findings show that children can construct diverse and fluid ethnic identities depending upon the interactional circumstances they encounter in different contexts. We were able to capture this fluidity because the focal child was observed across different schools and across different peer groups. The concept of a nexus of multimembership in diverse communities of practice (Wenger, 1998) helped deepen our understanding of the child's fluid ethnic identity construction because the fluidity emerged because of the child's participation in different communities of practice. The multiple ethnic identities are how she defines herself, which is unique and not necessarily consonant with others' descriptions of her (Harklau, 2000; Kang \& Lo, 2004). Bilingual children who engage in multiple communities combine their multiple memberships with their linguistically and culturally diverse experiences to construct their identities (Cho, 2016). As Wenger (1998) stated, “our various forms of participation delineate pieces of a puzzle we put together rather than sharp boundaries between disconnected parts of ourselves" (p. 159). It is important to consider multiple settings because bilingual and bicultural children integrate their experiences from multiple communities of practice to shape who they are (Wenger, 1998).

\section{Conclusions}

Due to the developmental and cognitive focus of existing quantitative research on young children's ethnic identity (e.g., Connolly, 2011; Doucet et al., 2018) and the age focus on adolescents of existing qualitative research (e.g., Harklau, 2000; Kang, 2013; Yoon, 2015), we know little about young bilingual children's ethnic identity that develops in interactions across social contexts. Our study addresses this gap by presenting a "telling case" (Mitchell, 1984) of a seven-year old bilingual child's discursive ethnic identity formation across multiple settings. By following Meeso's experience across different educational settings and across different peer 
groups, our study highlights the discursive and transactional relationships between the self, language use, and context. Our study demonstrates that Meeso's multiple memberships to different communities of practice and her flexible positionings across different contexts shape who she is.

These findings illustrate the importance of creating a school context that values and promotes diversity. Such an environment might allow bilingual children to flexibly explore and construct their ethnic identity (Harklau, 2000; Gonzalez, 2009; Toohey, 1998). One way to create such a safe school context is to educate both teachers and students about the asset-oriented perspective towards different ethnicities and multiculturalism/multilingualism (Nieto \& Bode, 2018). Such multicultural education can help teachers and students understand that no ethnicity is inferior and prevent any ethnic group of students from being marginalized.

There are, however, some inherent limitations in our study. First, this case study focused on a single child and mainly relied on observation as a source of data. Thus, the findings relate to this child and the situation could be different for other bilingual and ethnically diverse groups or children. In addition, ethnic identity development has been observed to vary across different ethnic groups (e.g., Latino, African American, Asian American; Crocker et al., 1994), across different individuals within the same situation, and within the same individuals across different situations (Yip, Douglass, \& Shelton, 2013). The current study mainly considered educational contexts within which an individual child's life is embedded. While some ethnic identity construction processes can be similar to those in other contexts, some contextual factors could have impacted the findings that include but are not limited to geography, gender, the topics that are discussed (e.g., childhood memories, food, kindship; Kang, 2013), teacher's views of students as deficient (Toohey, 1998), support of peers who have the same heritage (Gonzalez, 
2009), peers' views of bilingualism (Creese et al., 2006), and peers' views of multiculturalism (Yoon, 2015). Thus, generalizing the findings from a single-child case to other bilingual children, which is not a goal of the present case study, can be potentially misleading.

Second, due to limited space, this work does not include data the first author collected from the child's home (Cho, 2018). How children construct and negotiate their ethnic identities might be different between home and school (Huang \& Stormshak, 2011). In particular, while young children's ethnic identities are largely reinforced by family and peers, adolescents' ethnic identities are more affected by extra-familial socialization experiences and expanded social demands (Umaña-Taylor et al., 2014). While the impact of non-familial social interactions (in school, with peers) on the ethnic identity construction increases when a child starts formal schooling (Huang \& Stormshak, 2011; Umaña-Taylor et al., 2014), the family can still have a strong influence on a seven-year-old's ethnic identity construction. Future studies should examine interactions at home as well as outside home interactions for a more comprehensive understanding of a child's multilingual or multicultural identity development. 


\section{References}

Brown, C. L. (2009). Heritage language and ethnic identity: A case study of Korean-American college students. International Journal of Multicultural Education, 11(1), 1-16.

Brown, G., \& Yule, G. (1983). Discourse analysis. Cambridge: Cambridge University Press.

Bucholtz, M., \& Hall, K. (2005). Identity and interaction: a sociocultural linguistic approach. Discourse Studies, 7(4-5), 585-614.

Cho, G. (2000). The role of heritage language in social interactions and relationships: Reflections from a language minority group. Bilingual Research Journal, 24(4), 333-348.

Cho, H. (2016). Formal and informal academic language socialization of a bilingual child. International Journal of Bilingual Education and Bilingualism, 19(4), 387-407.

Cho, H. (2018). Korean-English bilingual sibling interactions and socialization. Linguistics and Education, 45, 31-39.

Connolly, P. (2011). Using survey data to explore preschool children's ethnic awareness and attitudes. Journal of Early Childhood Research, 9(2), 175-187.

Corsaro, W. (1997). The sociology of childhood. Thousand Oaks, CA: Pine Forge.

Creese, A., Bhatt, A., Bhojani, N., \& Martin, P. (2006). Multicultural, heritage and learner identities in complementary schools. Language and Education, 20(1), 23-43.

Crocker, J., Luhtanen, R., Blaine, B., \& Broadnax, S. (1994). Collective self-esteem and psychological well- being among White, Black, and Asian college students. Personality and Social Psychology Bulletin, 20, 503-513.

Davies, B., \& Harré, R. (1999). Positioning and personhood. In R. Harré \& L. van Langenhove (Eds.), Positioning theory (pp. 32 - 52). London: Sage. 
Doucet, F., Banerjee, M., \& Parade, S. (2018). What should young Black children know about race? Parents of preschoolers, preparation for bias, and promoting egalitarianism. Journal of Early Childhood Research, 16(1), 65-79.

Gonzalez, R. (2009). Beyond affirmation: How the school context facilitates racial/ethnic identity among Mexican American adolescents. Hispanic Journal of Behavioral Sciences, $31(1), 5-31$.

Hall, S. (1990). Cultural identity and diaspora. In J. Rutherford (ed.), Identity: Community, culture, difference. London: Lawrence and Wishart.

Harklau, L. (2000). From the "good kids" to the "worst": Representations of English language learners across educational settings. TESOL Quarterly, 34, 35-67.

Hollway, W. (1984). Gender difference and the production of subjectivity. In J. Henriques, W. Hollway, C. Venn, \& V. Walkerdine (Eds.), Changing the subject (pp. 223-261). London: Methuen.

Hornberger, N. H., \& Wang, S. (2008). Who are our heritage language learners? Identity and biliteracy in heritage language education in the United States. In D. Brinton, O. Kagan, \& S. Bauckus (Eds.), Heritage language education: A new field emerging (pp. 3-35). New York: Routledge.

Huang, C. Y., \& Stormshak, E. A. (2011). A longitudinal examination of early adolescence ethnic identity trajectories. Cultural Diversity and Ethnic Minority Psychology, 17(3), 261-270.

Hymes, D. (1974). Foundations of sociolinguistics: An ethnographic approach. Philadelphia: University of Pennsylvania Press.

Jenkins, R. (1994). Rethinking ethnicity: Identity, categorization and power. Ethnic and Racial 
Studies, 17(2), 197-223.

Jo, H. (2001). Heritage language learning and ethnic identity: Korean Americans' struggle with language authorities. Language, Culture and Curriculum, 14(1), 26-41.

Kang, H-S. (2013). Korean American college students' language practices and identity positioning: 'Not Korean, but not American.' Journal of Language, Identity, and Education, 12(4), 248-261.

Kang, M. A., \& Lo, A. (2004). Two ways of articulating heterogeneity in Korean American narratives of ethnic identity. Journal of Asian American Studies, 7(2), 93-116.

Marks, A. K., Szalacha, L. A., Lamarre, M., Boyd, M. J., \& Coll, C. G. (2007). Emerging ethnic identity and interethnic group social preferences in middle childhood: Findings from the Children of Immigrants Development in Context (CIDC) study. International Journal of Behavioral Development, 31(5), 501-513.

Mitchell, J. C. (1984). Typicality and the case study. In R. Ellen (Ed.), Ethnographic research: $A$ guide to general conduct (pp. 238-241). New York, NY: Academic Press.

National Center for Educational Statistics. (2015). Common Core of data 2014-2015 school year. Retrieved from http://nces.ed.gov/ccd/schoolsearch/

Nieto, S., \& Bode, P. (2018). Affirming diversity: The sociopolitical context of multicultural education ( $7^{\text {th }}$ ed.). Hoboken, NJ: Pearson.

Pavlenko, A., \& Blackledge, A. (2004). Introduction: New theoretical approaches to the study of negotiation of identities in multilingual contexts. In A. Pavlenko \& A. Blackledge (Eds.), Negotiation of identities in multilingual contexts (pp. 34-67). Clevedon: Multilingual Matters. 
Phinney, J. S. (1990). Ethnic identity in adolescents and adults: Review of research. Psychological Bulletin, 108, 499-514.

Phinney, J. S., Romero, I., Nava, M., \& Huang, D. (2001). The role of language, parents, and peers in ethnic identity among adolescents in immigrant families. Journal of Youth and Adolescence, 30(2), 135-153.

Quintana, S. M. (1998). Children's developmental understanding of ethnicity and race. Applied \& Preventive Psychology, 7(1), 27-45

Rampton, B. (1995). Crossing: Language and ethnicity among adolescents. New York: Longman.

Ritchie, S. M. (2002). Student positioning within groups during science activities. Research in Science Education, 32, 35-54.

Saville-Troike, M. (2003). The ethnography of communication ( $3^{\text {rd }}$ ed.). Oxford, UK: Blackwell Publishing.

Tajfel, H., \& Turner, J. C. (1986). The social identity theory of intergroup behavior. In S. Worchel \& W. G. Austin (Eds.), Psychology of intergroup relations (pp. 7-24). Chicago: Nelson Hall.

Thompson, R. (2006). Bilingual, bicultural, and binominal identities: Personal name investment and the imagination in the lives of Korean Americans. Journal of Language Identity, and Education, 5(3), 179-208.

Tse, L. (2000). The effects of ethnic identity formation on bilingual maintenance and development: An analysis of Asian American narratives. International Journal of Bilingualism Education and Bilingualism, 3(3), 185-200. 
Toohey, K. (1998). "Breaking them up, taking them away": ESL students in grade 1. TESOL Quarterly, 32(1), 61-84.

Umaña-Taylor, A. J., Quintana, S. M., Lee, R. M., Cross, W. E., Rivas-Drake, D., Schwartz, S. J., .. \& Ethnic and Racial Identity in the 21st Century Study Group. (2014). Ethnic and racial identity during adolescence and into young adulthood: An integrated conceptualization. Child Development, 85, 21-39.

U.S. Census Bureau. (2010). 2010 Census data. Retrieved from http://www.census.gov/2010census/data/

van Langenhove, L., \& Harré, R. (1999). Introducing positioning theory. In R. Harré \& L. van Langehove (Eds.), Positioning theory: Moral context of intentional action. Oxford: Blackwell.

Wenger, E. (1998). Communities of practice: Learning, meaning, and identity. New York: Cambridge University Press.

Yin, R. (2018). Case study research and applications: Design and methods ( $6^{\text {th }}$ ed.). Thousand Oaks, CA: Sage.

Yip, T., Douglass, S., \& Shelton, J. N. (2013). Daily intragroup contact in diverse settings: implications for Asian adolescents' ethnic identity. Child development, 84(4), 1425-1441.

Yoon, B. (2015). Cultural capital, agency, and voice: Literacy practices of middle school English language learners. Middle Grades Review, 1(2), 1-13.

You, B.-k. (2005). Children negotiating Korean American ethnic identity through their heritage language. Bilingual Research Journal, 29(3), 711-722. 